\title{
The Impact of Future Climate Change on Water Availability in Gusau, Zamfara State, Nigeria
}

\author{
Kanoma M.S. and Abdulkadir M. \\ Federal University Gusau, \\ Nigeria \\ Email: smkanoma@gmail.com
}

\begin{abstract}
Climate change has continued to pose challenging global environmental problems in the $21^{\text {st }}$ century. For instance, studies have shown that water resources quantity and quality will be seriously degraded by the phenomenon. This paper examines the effect of climate change on future water availability in Gusau City, Zamfara State, Nigeria. The data obtained from three Regional Climate Models (RCMs) ensembles gridded at $0.5^{\circ} \times 0.5^{\circ}$ spatial resolutions were used. The analysis was carried out using ArcGIS (ArcMap, version 10.5) software and comparison of the outcome of the three ensembles was made. The findings show future temperature increase as $1-3^{\circ} \mathrm{C}$ by $2040,3^{\circ} \mathrm{C}$ by 2070 and $2-5^{\circ} \mathrm{C}$ by 2100. Furthermore, future rainfall will increase under rcp 4.5 and 8.5 by $6.7 \%-20 \%, 10 \%-20 \%$ and $10 \%-30 \%$ by 2040, 2070v and 2100 respectively. It further shows an increase of $+10 \%$ to $+60 \%$ in seasonal changes of rainfall in the months of April-May-June and July-August-September respectively. These will ultimately result in the increase in surface run off and aquifer recharge. Similarly, the quality of water will also be degraded through sedimentation and nitrogen loading from farms, transport and dissolution of heavy metals by flooding. Therefore, the study recommends for the involvement in storm water harvesting and storage processes by both Government and other large scale water users.
\end{abstract}

Keywords: Climate Change, Temperature, Precipitation, Water Availability

\section{INTRODUCTION}

Climate change occasioned by the growing concentration of the greenhouse gases (GHGs) in the atmosphere, is widely considered to be one of the most pressing global environmental challenge of the 21st century. Inter-governmental Panel on Climate Change (2014) argues that recent anthropogenically induced global warming is unprecedented as far as the current understanding of the climate system is concerned. Although, the extent of human involvement in climate change has generated serious debates among scientific community, empirical studies have however shown that human being is the prime driver of the phenomena. For example, Heinzeller et al. (2018) reported that economic and population growth has substantially driven the GHGs emissions, as the latter will invariably bring high production and energy consumption. The concentration of carbon dioxide in the atmosphere accounted for $65 \%$ of the GHGs; in addition to methane $(17 \%)$ and nitrous oxide $(6 \%)$ (European Commission, 2018). It is significant to note that a great deal of the global warming effects occurred in the last 50 years of the previous century, with the last 3 decades being the warmest. However, dry lands are expected to be $40 \%$ warmer than the humid (Huang et al., 2017). Thus, dry areas become drier and wet areas wetter. 
Africa was warmer by $0.5^{\circ} \mathrm{C}$ in the last century and $0.5-0.8^{\circ} \mathrm{C}$ from $1970-2010$ (Niang et al., 2014). Most parts of the continents are projected to experience similar pattern (Nikulin et al., 2018). The continent is gradually warming although at a rate below global average by about $50 \%$. In an ideal situation, this ought to be worrisome in a continent that has poor coping strategy and over dependence on rain fed agriculture. Many empirical studies have shown that global warming intensifies hydrological cycle and thus destabilizes the water balance (Tabari et al., 2015; Greve et al., 2018). Against this backdrop, many climate projections predict increasing precipitation in Africa. Similarly, regions of the continent with higher population are projected to be affected more in terms of water decrease than sparsely populated areas. For instance, Akpodiogaga-a \& Odjugo, (2010) studied trend in Nigerian rainfall and reported $81 \mathrm{~mm}$ decrease in the last century.

Moseki (2017) established that groundwater recharge will drop by $80 \%$ in areas receiving $500 \mathrm{~mm}$ when precipitation decline by $20 \%$. This implies that under climate change the freshwater resources vulnerability will be higher. Similarly, Abdullahi et al. (2014) found that Sokoto Rima region will experience less freshwater availability by 1.7 billion $\mathrm{m}^{3}$ annually under $10 \%$ reduction in precipitation. Being part of the Rima Region, Gusau City is one of the water scarce areas due to over dependence on underground water by household and businesses for domestic and industrial use respectively. The City suffers from perennial water crisis during every drought season as aquifer depletion is common during this season. The cumulative effect of natural climate variability and climate change further complicate the problem. Despite these, there is either very little or no research on this subject in the City. This paper therefore aims at examining the impact of climate change on future water availability in Gusau City.

\section{MATERIAL AND METHODS}

\section{Study area}

Gusau, the study area, is the capital City of Zamfara State of Nigeria. It lies on latitude $12.1702^{\circ} \mathrm{N}$ and longitude $6.6641^{\circ} \mathrm{E}$ and elevated to $451 \mathrm{~m}$ above sea level (Figure 1). 


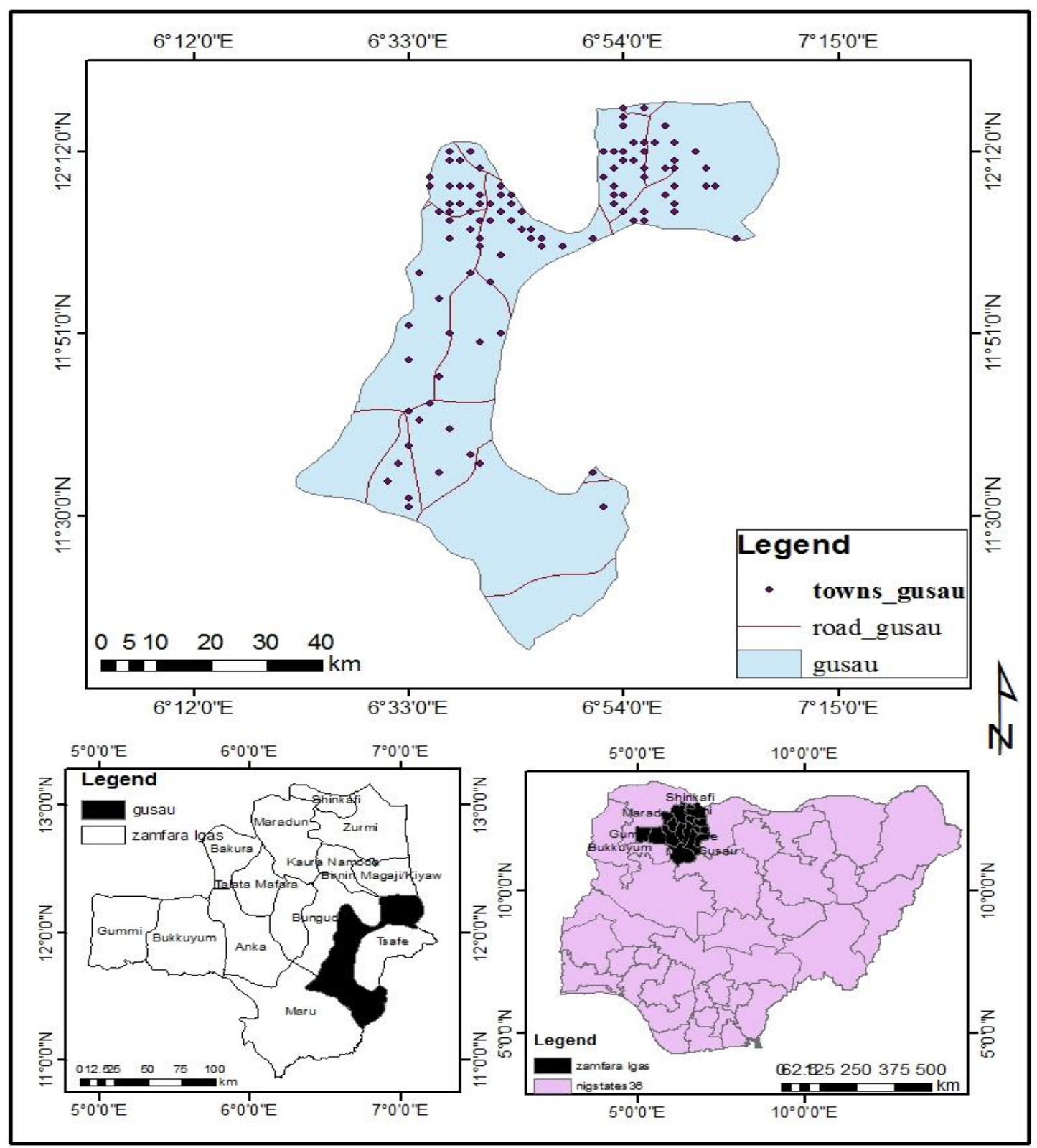

Figure 1: Map of the study area

The climate of Gusau is a typical semiarid/arid climate type. It is influenced by the north moving moist and south moving dry continental air masses, resulting in two alternate rainy and dry seasons respectively (Ayoade 2004). The moist air from the south brings five months rainy season (June to October), while the dust laden dry air from the Sahara desert results in three (3) months of Harmattan cold season, (December to February) in the area. The air masses are divided by zigzag moving surface called Inter Tropical Discontinuity. Similarly, the City receives an average annual precipitation of $868 \mathrm{~mm}$ and experience $26.3^{\circ} \mathrm{C}$ of temperature annually (Climatedata.eu, 2018). The geology of the area is characterized as that of typical Northern Nigeria plain better known as plains of Hausa land. It is generally underlain by Precambrian era basement complex rocks. Granite and gneiss are the common extrusion of once intrusive igneous family in the area (Swindel, Boyd \& McCarthy, 1982). The City falls within Sudan savannah vegetation zone. This vegetation belt is characterised by being predominantly short grasses and scattered trees of predominantly thorny and locust bean type (Udo 2003). The area is drained by River Sokoto which originated from near Funtua 
highland in the neighbouring Katsina State, crossing Gusau, Sokoto and eventually joins River Niger in Kebbi State.

\section{Materials}

The materials used in this work are both computer hardware and software. These include HP laptop computer, Intel Core i5, vPro, used for data processing and analysis. The Global Positioning System (GPS) hand receiver was employed for capturing coordinates of the study area. ArcGIS software (ArcMap, version 10.5), Windows 10 Pro, version $20 \mathrm{H} 2$ and Microsoft office word 2010, were used in downloading and processing the climate projection data, and typing the work respectively.

\section{Data collection}

Future projection of the climate data spanning the entire century (2000-2100) was acquired from the internet archives (Dosio \& Panitz, 2015; Jones, 2017; Heinzeller et al., 2018). The data is made up of three different Regional Climate Models as follows: COSMO-CLM (CCLM), WASCAL WRF, and RCA4 (Table 1). The climate data derived from these models were used to assess climate change impacts on water resources availability in Gusau City.

Table 1: Climate models and their attributes

\begin{tabular}{|c|c|c|c|c|c|c|}
\hline $\begin{array}{l}\text { Projects } \\
\text { names }\end{array}$ & $\begin{array}{l}\text { Driving } \\
\text { GCMs }\end{array}$ & $\begin{array}{l}\text { Spatial } \\
\text { Resolution }\end{array}$ & Domain & Control Period & Future Periods & Source \\
\hline $\begin{array}{l}\text { COSMO- } \\
\text { CLM }\end{array}$ & 4 & $50 \mathrm{~km}$ & $\begin{array}{l}\text { CORDEX } \\
\text { Africa }\end{array}$ & $1981-2010$ & $2071-2100$ & $\begin{array}{l}\text { Dosio and } \\
\text { Panitz 2015 }\end{array}$ \\
\hline $\begin{array}{l}\text { WASCAL } \\
\text { WRF }\end{array}$ & 3 & $\begin{array}{l}12 \mathrm{~km} \text { and } \\
60 \mathrm{~km}\end{array}$ & West Africa & $1980-2010$ & $\begin{array}{l}2030-2050 \text { and } \\
2070-2100\end{array}$ & $\begin{array}{l}\text { Heinzeller et al } \\
2018\end{array}$ \\
\hline RCA4 & 8 & $50 \mathrm{~km}$ & $\begin{array}{l}\text { CORDEX } \\
\text { Africa }\end{array}$ & 1979-2010 & $\begin{array}{l}2011-2040, \\
2041-2070 \\
2071-2100\end{array}$ & $\begin{array}{l}\text { Jones et al. } \\
2017\end{array}$ \\
\hline
\end{tabular}

\section{Data Analysis}

Comparative analytical method using ArcGIS was employed as in Tabari et al. (2015) and Greve et al. (2018). The evaluation was made using the models and the data sorted for analysis.

The chosen baseline period of 1981-2010 is common to the three models ensemble used here. Similarly, three slices of the future employed; 2040 (2011-2050), 2070 (2051-2070) and 2100 (2071-2100) is to make the research relevant to both current and future generation. Furthermore, the Representative Concentration Pathways 4.5 and 8.5 were used although they are common only to RCA4 and CCLM ensembles and not to WASCAL. This is to give more than one option to decision makers who may wish to have multiple options. The RCA4 and WASCAL WRF as opposed to CCLM are the models that projected for the future period of 2040 and 2070, therefore the findings for the periods in reference would be from these model ensembles. In a similar circumstance, only RCA4 and CCLM projected under rcp 8.5 pathways, so the result presented was from these models. Using the baseline data, all the units attached to precipitations were normalised to percentage. While the ensembles output were represented on maps, separate analyses were made for temperature and precipitation in respect to the models ensemble. In the major finding section, the results of the three or two models as the case may be were compared and given as range of values. Finally, the major findings as it relate to the future changes in temperature and precipitation is linked to water 
availability in the discussion section.

\section{RESULTS}

The result derived from Regional Climate Models (RCMs) comprising of future temperature and precipitation changes of the study area is presented in this section.

\section{Temperature projection over Gusau City}

Future temperature projections for Gusau City were derived from each of the three models namely the COSMO- CLM (CCLM), the WASCAL WRF, and the RCA4.

\section{RCA4 Future temperature projection (2011 - 2100)}

Figure 2 presented the future changes by the years 2040, 2070 and 2100, of mean surface temperature as simulated by RCA4 ensembles. The result indicates an increase in temperature ranging from $2^{\circ} \mathrm{C}-3^{\circ} \mathrm{C}$ under rcp 4.5 and $2^{\circ} \mathrm{C}-5^{\circ} \mathrm{C}$ under rcp 8.5. Further details of the changes on the basis of future periods is summarise in Table 2.

Table 2: Summary temperature change for the 3 slices of the $21^{\text {st }}$ century

\begin{tabular}{lllll}
\hline RCP scenario & 2040 & 2070 & 2100 & overall change \\
\hline rcp 4.5 & $2{ }^{\circ} \mathrm{C}$ & $3{ }^{\circ} \mathrm{C}$ & $3{ }^{\circ} \mathrm{C}$ & $2{ }^{\circ} \mathrm{C}-3{ }^{\circ} \mathrm{C}$ \\
rcp 8.5 & $2^{\circ} \mathrm{C}$ & $3^{\circ} \mathrm{C}$ & $5^{\circ} \mathrm{C}$ & $2^{\circ} \mathrm{C}-5^{\circ} \mathrm{C}$ \\
\hline
\end{tabular}

Source: Jones (2017)

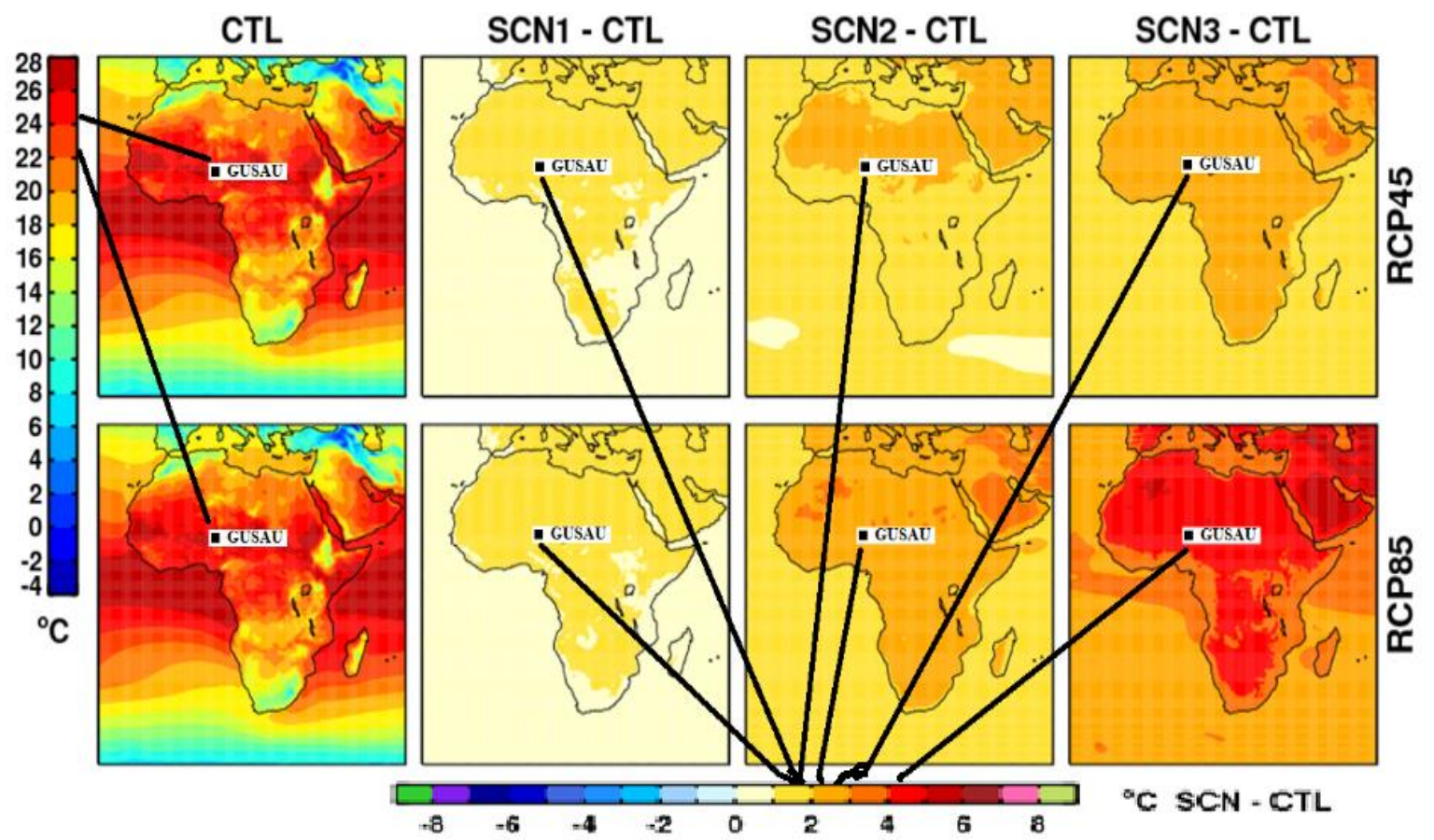

Figure 2: 30 year annual mean, 6 member ensembsle mean temperature change for the CTL: 1971 - 200, SCN1: 2011 - 2040, SCN2: 2041 - 2070 and SCN3: 2071 - 2100 (Jones, 2017)

\section{WASCAL WRF Ensemble: Temperature Projection (2011 -2100)}

In Figure 3 below, the simulated changes in mean temperature in the study area over the years $2020-2050$ and $2070-2100$ is presented. The result which compared the baseline and projected temperatures as simulated by WASCAL shows an increase of $1{ }^{\circ} \mathrm{C}$ by 2050 and $2{ }^{\circ} \mathrm{C}$ by 2070 2100 , suggesting a warmer Gusau over the $21^{\text {st }}$ century by $1-2^{\circ} \mathrm{C}$. 

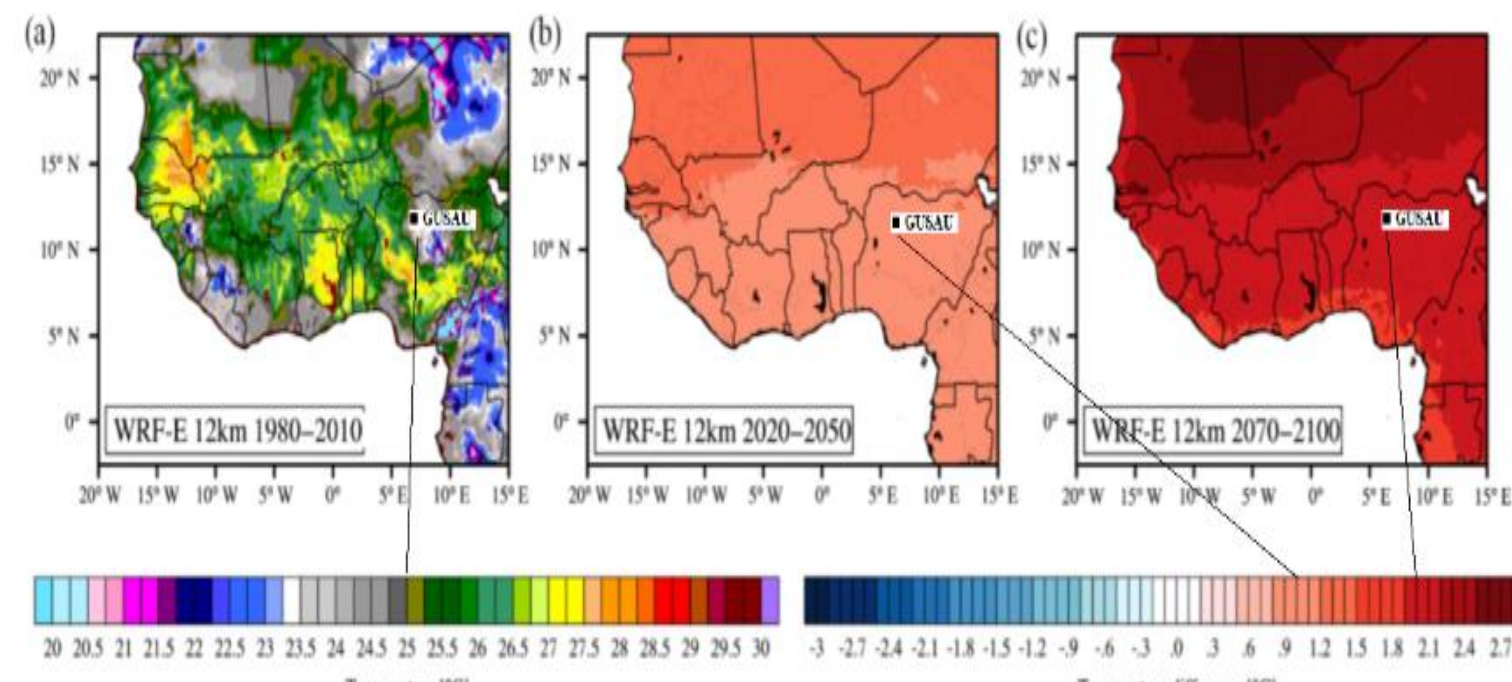

Tempeniture $|\mathrm{C}|$

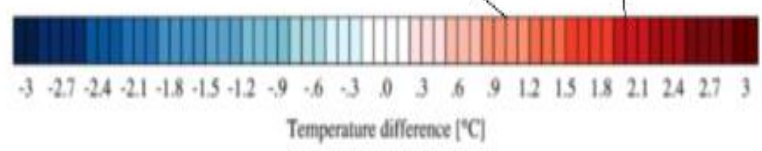

Figure 3: Projected surface temperature as simulated by WASCAL for the control period of 1980 - 2010(a), near future 2020 - 2050 (b) and the end of the 21st century 2070 - 2100 (c) (Heinzeller et al., 2018)

\section{CORDEX Africa CCLM: Temperature Projection (2071 - 2100)}

Baseline and projected temperature simulated for JFM and JAS seasons by CCLM is presented in Figure 4. Based on the results, the City of Gusau witnesses rise in temperature by $2-4.5^{\circ} \mathrm{C}$ in JFM and $2.5-5{ }^{\circ} \mathrm{C}$ in JAS over late part of this century. Table 3 shows more details of the changes.

Table 3: Projected seasonal temperature changes over Gusau

\begin{tabular}{lll}
\hline RCP scenario & JFM & JAS \\
\hline rcp 4.5 & $2^{\circ} \mathrm{C}$ & $2.5^{\circ} \mathrm{C}$ \\
rcp 8.5 & $4.5^{\circ} \mathrm{C}$ & $5^{\circ} \mathrm{C}$ \\
overall change & $2^{\circ} \mathrm{C}-4.5^{\circ} \mathrm{C}$ & $2.5^{\circ} \mathrm{C}-5^{\circ} \mathrm{C}$ \\
\hline
\end{tabular}

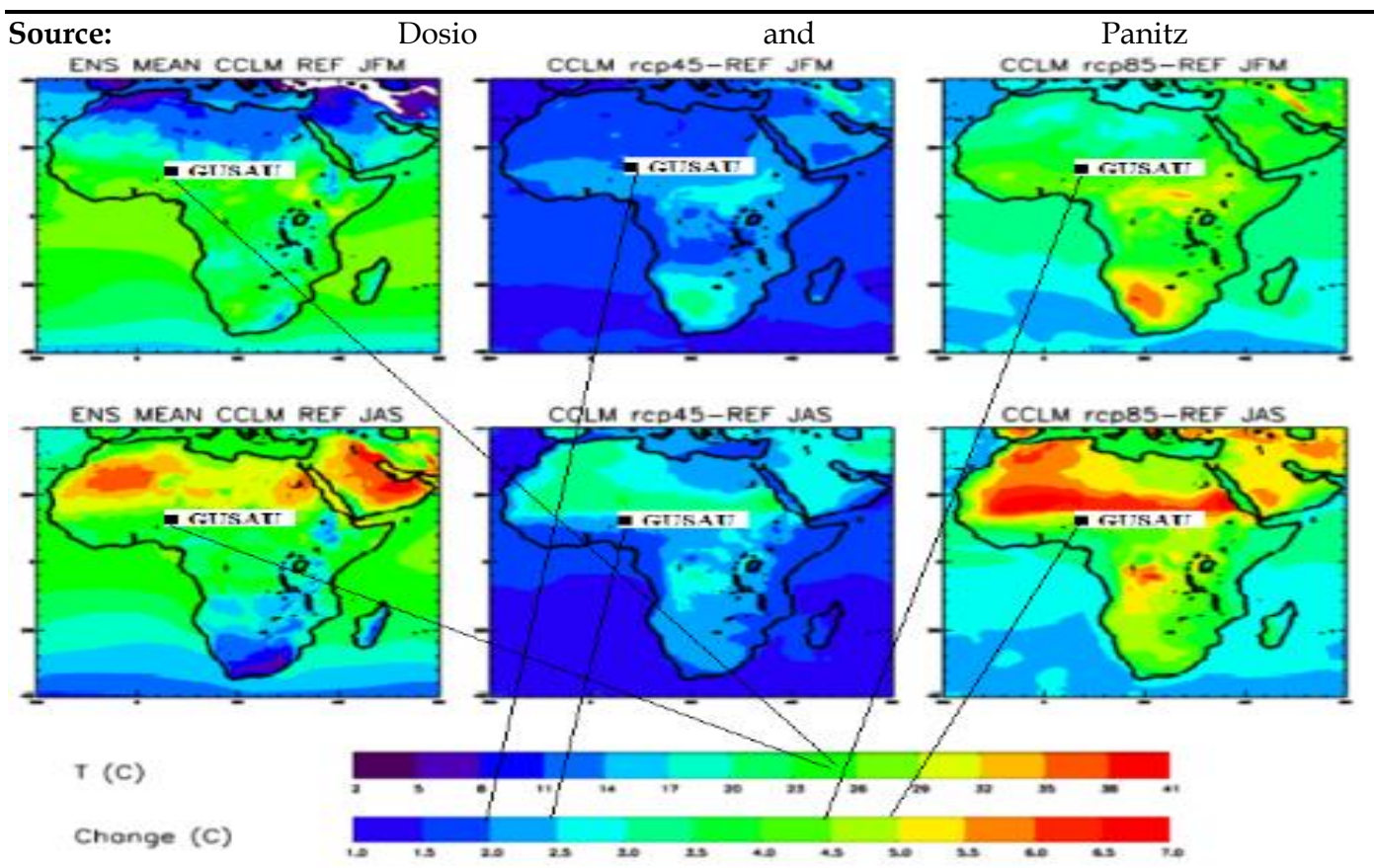

Figure 4: Seasonal mean temperature as simulated by the ensemble of CCLM for the JFM and JAS seasons (Dosio and Panitz, 2015) 


\section{Precipitation Projection over Gusau City}

RCA4 Ensemble: Precipitation Projection (2011 - 2100)

The City of Gusau in Figure 5 below is projected to experience an increase in precipitation base on the RCA4 simulation. The magnitude of the changes under rcp 4.5 and 8.5 indicated $+10 \%$ and $+20-30 \%$ respectively (Table 4 ).

Table 4: Projected precipitation changes over Gusau City in 21 st century

\begin{tabular}{lllll}
\hline RCP scenario & $\mathbf{2 0 4 0}$ & $\mathbf{2 0 7 0}$ & $\mathbf{2 1 0 0}$ & overall change \\
\hline rcp 4.5 & $10 \%$ & $10 \%$ & $10 \%$ & $10 \%$ \\
$\operatorname{rcp} 8.5$ & $20 \%$ & $20 \%$ & $30 \%$ & $20 \%-30 \%$ \\
\hline
\end{tabular}

Source: Jones (2017)

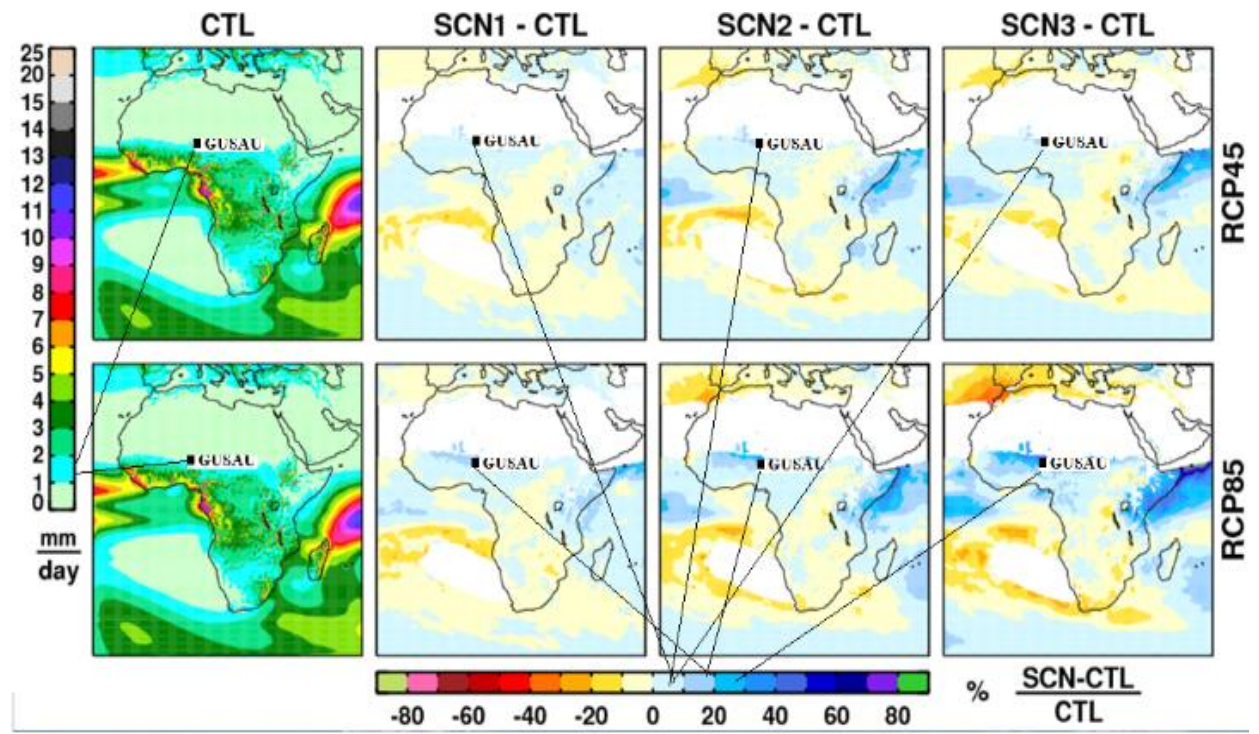

Figure 5: 30 year ensemble mean precipitation changes for the control period (CTL) 1979 - 2010, SCN1 (2011-2040), SCN2 (2041 - 2070) and SCN1 (2071 - 2100) (Jones, 2017)

\section{RCA4 ensemble seasonal precipitation changes (2071 - 2100)}

Seasonal changes in precipitation in Gusau City over the late part of the $21^{\text {st }}$ century (under rcp 8.5) are indicated in Figure 6. While the rainfall is projected to moderately increase $(10 \%)$ in April-May-June, the changes is much higher in July-August-September seasons with $60 \%$ increase. The simulated changes clearly captured West African Monsoon. However, the changes in January-February-March and October-November-December seasons are not statistically significant.

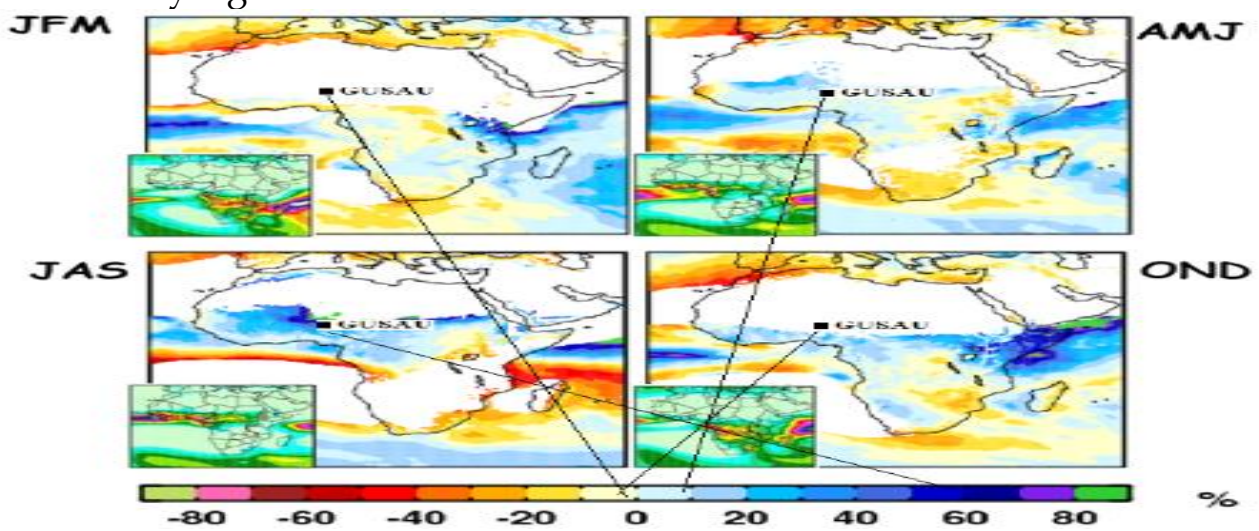

Figure 6: Seasonal mean precipitation changes for JFM, AMJ, JAS and OND (Jones, 2017) 
WASCAL WRF Ensemble: Precipitation Projection over Gusau (2011 - 2100)

Mean precipitation changes over Gusau in the mid and late 21st century in relation to the baseline period of 1980-2010 are presented in Figure 7. The changes indicated that under rcp 4.5 , a precipitation increase of $+75 \mathrm{~mm}$ and $+150 \mathrm{~mm}$ respectively in 2050 and 2100 is projected. The magnitude of the precipitation changes shows an increase of $+100 \mathrm{~mm}-150 \mathrm{~mm}$ equivalent to $6.7-10 \%$ respectively.
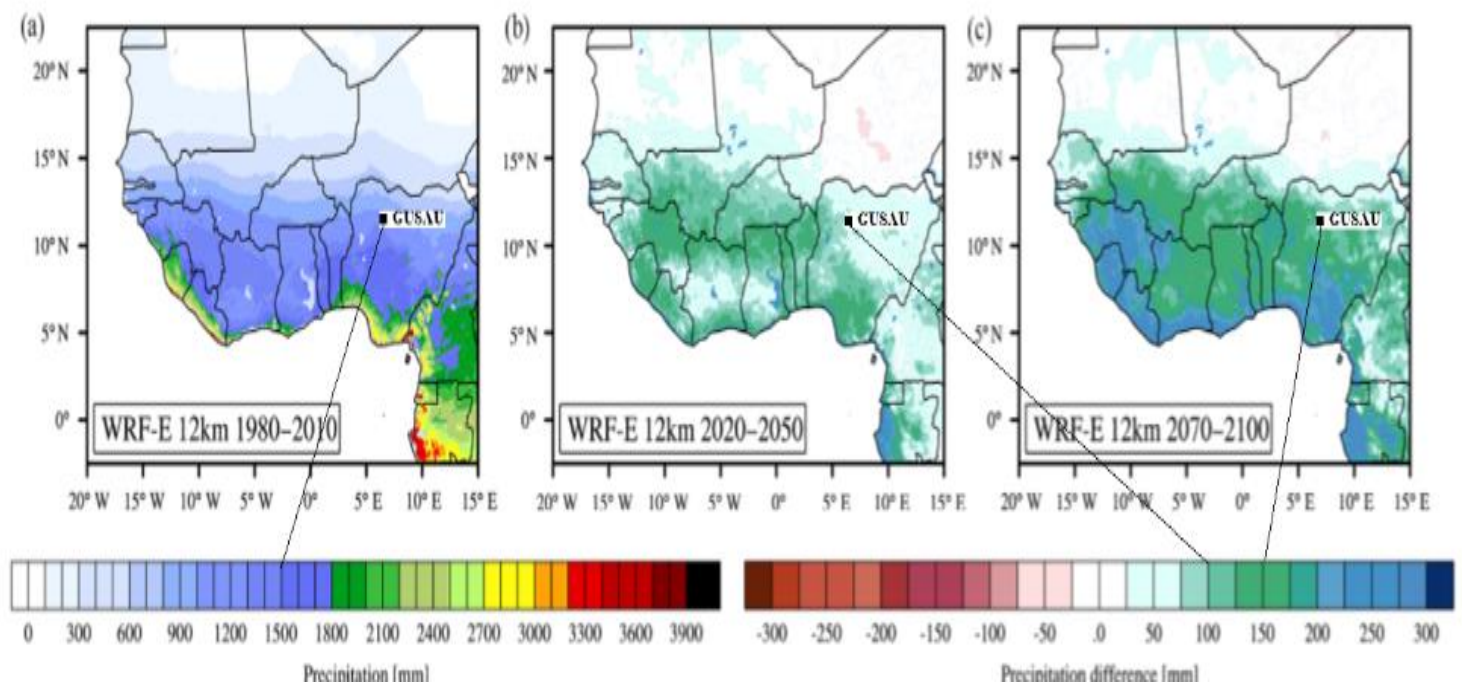

Figure 7: Projected Annual precipitation simulated by WASCAL for the control period (1980-2010) (a), 2020-2050 (b) and the end of the 21st century 2070-2100 (c) (Heinzeller et al. 2018)

\section{CORDEX Africa CCLM: Precipitation Projection over Gusau (2070 -2100)}

Simulated mean seasonal precipitation changes of historical baseline and projected periods are presented in Figure 8. On the basis of the projection of CCLM ensemble, the precipitation changes over the late century in JFM is $+0.1 \mathrm{~mm}$ and $-0.1 \mathrm{~mm}$. The changes may not be unconnected with the fact that JFM is cold season in the study area. In contrast, +0.25 and -1.5 changes in precipitation is projected in JAS under rcp 4.5 and 8.5 respectively.
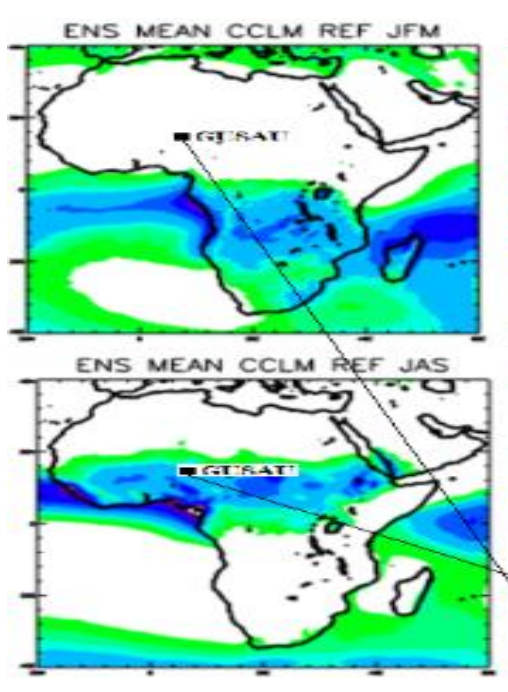

Precipitation ( $\mathrm{mm} / \mathrm{doy}$ )

Chonge $(\mathrm{mm} / \mathrm{doy})$

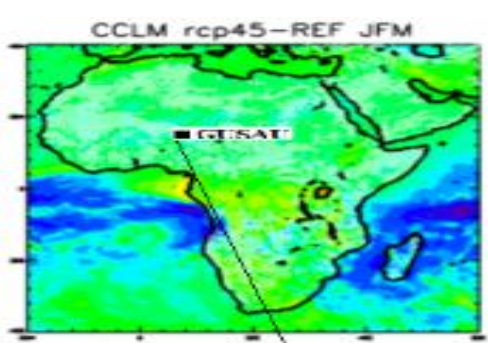

CCLM RCP 45 TREF JAS

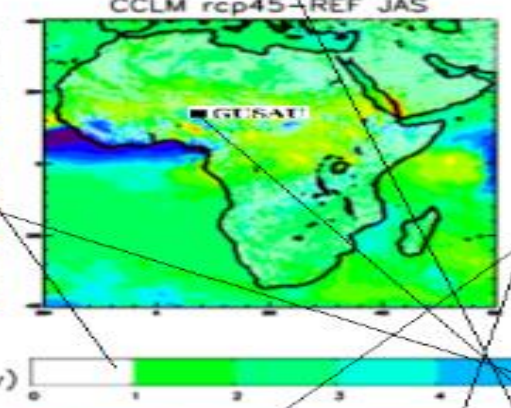

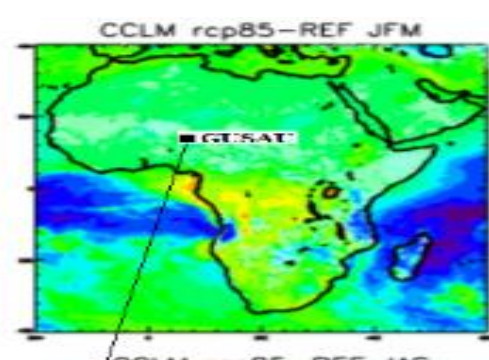

CCLM RCPBS-REF JAS
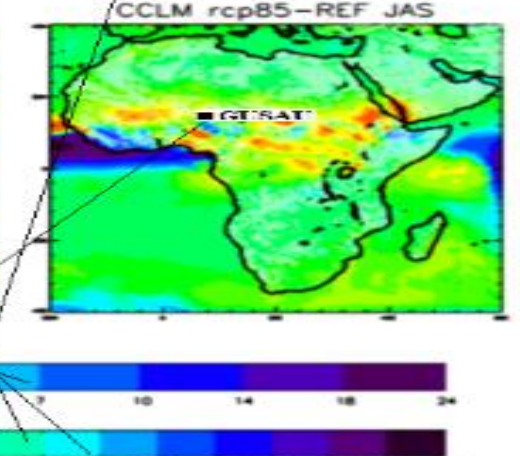

Figure 8: Seasonal mean precipitation as simulated by CCLM ensemble for JFM and JAS. Mean reference ensemble (left), rcp 4.5 (centre) and rcp 8.5 (right) (Dosio and Panitz, 2015) 


\section{DISCUSSION}

\section{Major Findings on Precipitation and Temperature Changes}

The precipitation and temperature projections from all the three models show an increase for the 3 slices of the future periods and under both rcps. The findings indicate precipitation increment of $6.7 \%-20 \%, 10 \%-20 \%$ and $10 \%-30 \%$, each by the years 2040,2070 and 2100 under rcp 4.5 and 8.5 respectively. There will also be increase in seasonal changes in precipitation in the months AMJ and JAS by $+10 \%-60 \%$ over the late part of this century. The findings deviated from the findings of Akpodiogaga-a \& Odjugo, (2010) who found decrease in their work. This may not be unconnected with the fact that the researchers used historical data as against projected data used in this work. Similarly, the temperature increases by $1-3{ }^{\circ} \mathrm{C}, 3^{\circ} \mathrm{C}, 2-5^{\circ} \mathrm{C}$ by the respective years of 2040,2070 and 2100 under rcp 4.5 and rcp 8.5 pathways. This conforms to the findings of Niang et al. (2014) who found temperature increase over Africa.

\section{Climate Change and Water Availability}

The findings of this paper show that precipitation in the study area will demonstrate a corresponding increment to that of temperature. At the same time, the increment in precipitation will be manifested in major aspects of hydrological cycle like surface runoff and groundwater recharge (Moseki, 2017). The resultant effect of this will be witness in the availability of water resources. Furthermore, many studies have argued in support of correlation between extreme weather events and amount of precipitation (IPCC, 2018; Kharin et al. 2018). The likelihood of higher occurrence of flooding over Gusau City, resulting from this projection, is very high. The consequences of this is that it will affects water quality by sedimentation and nitrogen loading as well as other pollutants into the water bodies (Whitehead et al., 2015; Wu et al., 2017; Loecke et al., 2017). It can also damage energy (electricity) and water supply infrastructures. The Nigeria's National Emergency Management Agency (2018) observed that the aftermath of flooding is sometimes devastating because it results in loss of lives, properties and infrastructural facilities (Orji, 2018). The increase in temperature, on the other hand, exacerbates hydrological cycle through high rate of evapotranspiration (Tabari et al. 2015; Greve et al. 2018). This will aggregate to high precipitation on one hand and higher demand on the other. Although the increasing population may affect water demand but rising temperature will affect its availability (Schewe et al. 2013). In the extreme, high rate of precipitation will not only have effect on ground water recharge but will also reduce the water quality and damage water supply infrastructure. The effect of rising temperature will lead to more water demand by increasing evapotranspiration.

\section{CONCLUSION AND RECOMMENDATIONS}

Using three models as the basis of its analysis, this research found incontrovertible empirical evidences of future climate change in Gusau City. Climatic variables investigated include increase in temperature and precipitation. The net effect of all these is intensification of hydrological cycle due to high temperature, freshwater increase due to high surface runoff and aquifer recharge as well as the reduction in water quality. Based on the foregoing, the study recommends to Zamfara State Government for the construction of water storages in many strategic locations within Gusau City for collection and treatment of storm water. The collected excess water should be treated and supplied for domestic and industrial use, especially during drought spells. Government can charge fees from the individual public and private organisations on the basis of their respective water requirements, land use and the role they play in polluting the drainages (and the general water pollution in the City). The State Government should also make it mandatory the involvement of large scale water users, in water harvesting and storage processes. Finally, the Government should embark on public 
enlightenment on the danger of anthropogenic activities that contributes to climate change and the need to imbibe, by the general public, water conservation measures.

\section{Acknowledgement}

This paper is an extract of an unpublished MSc Dissertation titled Climate Change and the Water Poverty in Gusau City, Zamfara State by Muhammad Samaila Kanoma, submitted to the Department of Environmental Management, Coventry University, UK (2019).

\section{REFERENCES}

Abdullahi S. A., Muhammad M., Adeogun B. K., and Mohammed I.U. (2014) 'Assessment of Water Availability in the Sokoto Rima River Basin. Resource and Environment 4(5), 220 233

Akpodiogaga-a, P. and Odjugo, O. (2010) ‘General Overview of Climate Change Impacts in Nigeria'. Journal of Human Ecology 29(1), 47-55

Ayoade, J.O. (2004) Introduction to Climatology for the Tropics. 2nd edn. Ibadan: Spectrum Books Limited

Berge, HFM (2019). R. Hijbeek, M.P. van Loon, J. Rurinda, K. Tesfaye, S. Zingore,

Climate Data (2018) Climate Gusau - Zamfara [online] available from $<$ https://www.climatedata.eu/climate.php?loc=nizz0003\&lang=en> [24 December 2018]

Dosio, A. and Panitz, H. (2015) 'Climate change projections for CORDEX-Africa with COSMO-CLM regional climate model and differences with the driving global climate models'. Climate Dynamics 46(5-6), 1599-1625

European commission (2018) Causes Of Climate Change - Climate Action - European Commission [online] available from <https://ec.europa.eu/clima/change/causes_en> [15 November 2018]

Felix, O., May, T., Giles, M., Giuseppina, S. and Frauke, U. (2017) 'Hope, Politics and Risk: The Case of Chinese Dam in Nigeria'. Energy and Environment Research 7(2), p.1.

Greve, P., Gudmundsson, L. and Seneviratne, S. (2018) 'Regional Scaling Of Annual Mean Precipitation And Water Availability With Global Temperature Change'. Earth System Dynamics 9 (1), 227-240

Heinzeller, D., Dieng, D., Smiatek, G., Olusegun, C., Klein, C., Hamann, I., Salack, S., Bliefernicht, J. and Kunstmann, H. (2018) 'The WASCAL High-Resolution Regional Climate Simulation Ensemble for West Africa: Concept, Dissemination And Assessment'. Earth System Science Data 10 (2), 815-835

Huang, J., Yu, H., Dai, A., Wei, Y. and Kang, L. (2017) ‘Drylands Face Potential Threat Under $2{ }^{\circ} \mathrm{C}$ Global Warming Target'. Nature Climate Change 7, 417-422

Inter-Governmental Panel for Climate Change (2014) Synthesis Report Contribution of Working Groups I, II and III to the Fifth Assessment Report of the Intergovernmental Panel on Climate Change. Geneva: IPCC, 151

Intergovernmental Panel for Climate Change (2018) Global warming of $1.5^{\circ} \mathrm{C}$ : a summary for policy makers [online] available from <http://www.ipcc.ch/news_and_events/pr_181008_P48_spm.shtml> [10 October 2018]

Jones, C. (2017) an ensemble of CORDEX-Africa climate projections simulated by RCA4 | SMHI [online] Available from <https://www.smhi.se/en/research/researchdepartments/climate-research-rossby-centre2-552/an-ensemble-of-cordex-africaclimate-projections-simulated-by-rca4-1.25312> [16 Nov. 2018] 
Kharin, V., Flato, G., Zhang, X., Gillett, N., Zwiers, F. and Anderson, K. (2018) 'Risks From Climate Extremes Change Differently From $1.5^{\circ} \mathrm{C}$ To $2.0^{\circ} \mathrm{C}$ Depending On Rarity'. Earth's Future 6 (5), 704-715

Loecke, T., Burgin, A., Riveros-Iregui, D., Ward, A., Thomas, S., Davis, C. and Clair, M. (2017) ‘Weather Whiplash In Agricultural Regions Drives Deterioration Of Water Quality'. Biogeochemistry 133 (1), 7-15

Moseki, M.C. (2017) 'Climate change impacts on groundwater: literature review'. Environ Risk Assess Remediat 2(1), 16-20

Niang, I., Ruppel, O.C., Abdrabo, M.A., Essel, N., Lennard, C., Padgham, J. and Urquhart, P. (2014) 'Africa'. In Climate Change 2014: Impacts, Adaptation, and Vulnerability. Part B: Regional Aspects. Contribution of Working Group II to the Fifth Assessment Report of the Intergovernmental Panel on Climate Change. Ed. by Barros, V.R., Field, C.B., Dokken, D.J., Mastrandrea, M.D., Mach, K.J., Bilir, T.E., Chatterjee, M., Ebi, K.L., Estrada, Y.O., Genova, R.C., Girma, B., Kissel, E.S., Levy, A.N., MacCracken, S., Mastrandrea, P.R. and White L.L. Cambridge: Cambridge University Press

Nikulin, G., Lennard, C., Dosio, A., Kjellström, E., Chen, Y., Hänsler, A., Kupiainen, M., Laprise, R., Mariotti, L., Maule, C., van Meijgaard, E., Panitz, H., Scinocca, J. and Somot, S. (2018) 'The Effects Of 1.5 And 2 Degrees Of Global Warming On Africa In The CORDEX Ensemble Environmental Research Letters 13 (6), 065003

Orji, S. (2018) It Rains, It Pours, It Floods: Nigeria's Growing Seasonal Problem - African Arguments [online] available from <https://africanarguments.org/2018/11/15/nigeria-floodsgrowing-problem/> [20 December 2018]

P. Craufurd, J. van Heerwaarden, F. Brentrup, J.J. Schroder, H.L. Boogaard, H.L.E. de Groot,, M.K. van Ittersum

Schewe, J., Heinke, J., Gerten, D., Haddeland, I., Arnell, N., Clark, D., Dankers, R., Eisner, S., Fekete, B., Colón-González, F., Gosling, S., Kim, H., Liu, X., Masaki, Y., Portmann, F., Satoh, Y., Stacke, T., Tang, Q., Wada, Y., Wisser, D., Albrecht, T., Frieler, K., Piontek, F., Warszawski, L. and Kabat, P. (2013) 'Multimodel Assessment Of Water Scarcity Under Climate Change'. Proceedings of the National Academy of Sciences 111 (9), 32453250

Swindel A, Boyd D. M., McCarthy (1982) Sokoto State in maps; an atlas of physical and Human Resources. Sokoto: University press limited.

Tabari, H., Taye, M. and Willems, P. (2015) ‘Water Availability Change in Central Belgium for the Late 21St Century'. Global and Planetary Change 131, 115-123

Udo, R. K. (1970) Geographical Regions of Nigeria. London: Heinemann Press

Whitehead, P., Barbour, E., Futter, M., Sarkar, S., Rodda, H., Caesar, J., Butterfield, D., Jin, L., Sinha, R., Nicholls, R. and Salehin, M. (2015) 'Impacts Of Climate Change And SocioEconomic Scenarios On Flow And Water Quality Of The Ganges, Brahmaputra And Meghna (GBM) River Systems: Low Flow And Flood Statistics'. Environmental Science: Processes $\mathcal{E}$ Impacts 17 (6), 1057-1069

World Atlas (2018) Where Is Gusau, Nigeria? [Online] available from <https://www.worldatlas.com/af/ng/za/where-is-gusau.html> [24 December 2018]

Wu, Q., Qi, J. and Xia, X. (2017) 'Long-Term Variations In Sediment Heavy Metals Of A Reservoir With Changing Trophic States: Implications For The Impact Of Climate Change'. Science of the Total Environment 609, 242-250 